\title{
A SAM-based General Equilibrium Model of the Pakistan Economy 1983-84
}

\author{
ShaFiQ Dhanani*
}

\section{INTRODUCTION}

Interest in Social Accounting Matrices as extensions of input-output tables has grown tremendously in the last ten years both for the purpose of obtaining a better descriptive analysis of the many intersectoral interdependencies in an economy and of household income distribution, and as data framework for macroeconomic modelling.

The objective of this paper is to make use of a social accounting matrix for Pakistan on one hand and a general equilibrium model framework on the other hand to gauge the quantitative impact on the country as a whole of alternative policy options and external shock scenarios. The policy options and external shocks simulated here and the economic indicators used for this purpose are shown in Table 1.

\section{Table 1}

\section{Policy Measures and Economic Indicators}

Policy Measures \& Scenarios

Increase in Investment

Increase in Government Expenditure

Increase in Indirect Tax

Increase in World Prices of Manufactures

Decrease in Remittances

\section{Economic Indicators}

\section{GDP}

Income Distribution (Rural/Urban and Poor/Other Households)

Rural and Urban Employment

Exports, Imports and Trade Balance Price of Capital

Price of Consumer Goods

\section{MODEL SPECIFICATION AND DATA REQUIREMENTS}

Due to space limitation it is not possible to give a complete and formal description of the model here, however its main features can be summarized as shown in

*The author is consultant at the Food and Agriculture Organization, Somalia. An earlier version of this paper was published as Report No. 88-1 by the Agricultural Economics Unit, Oxford University, in March 1988. 
Table 2 below. ${ }^{1}$ These are some of the major features and assumptions of the model, but certainly not the only ones. It should also be mentioned that the model requires a series of parameters, some of which are provided by the data SAM, and others which have to be provided, in particular factor substitution elasticities, and export

\section{Table 2}

\section{Major Features of the General Equilibrium Model for Pakistan}

\section{Features}

\section{Remarks}

1. Economy-wide Exercise

2. Flexible-price Model

3. CES Production Functions

4. LES Consumption Functions

5. Armington-type Import Specification

6. Elasticity of Demand for Exports

7. Keynesian Closure Rule: a. Fixed Capital Supply

b. Unlimited Labour Supply at Predetermined Wages

8. Use of Social Accounting Matrix for $1983-84$

9. Static Model

10. Open Economy

11. Model Implemented with the Help Developed and used by World Bank for of Hercules Software Package

'An extended version of this paper containing the mathematical formulation of the model, the SAM data base, the selected elasticity and other user-provided parameters and the complete listing of the computer input and output files is available on request from the author.

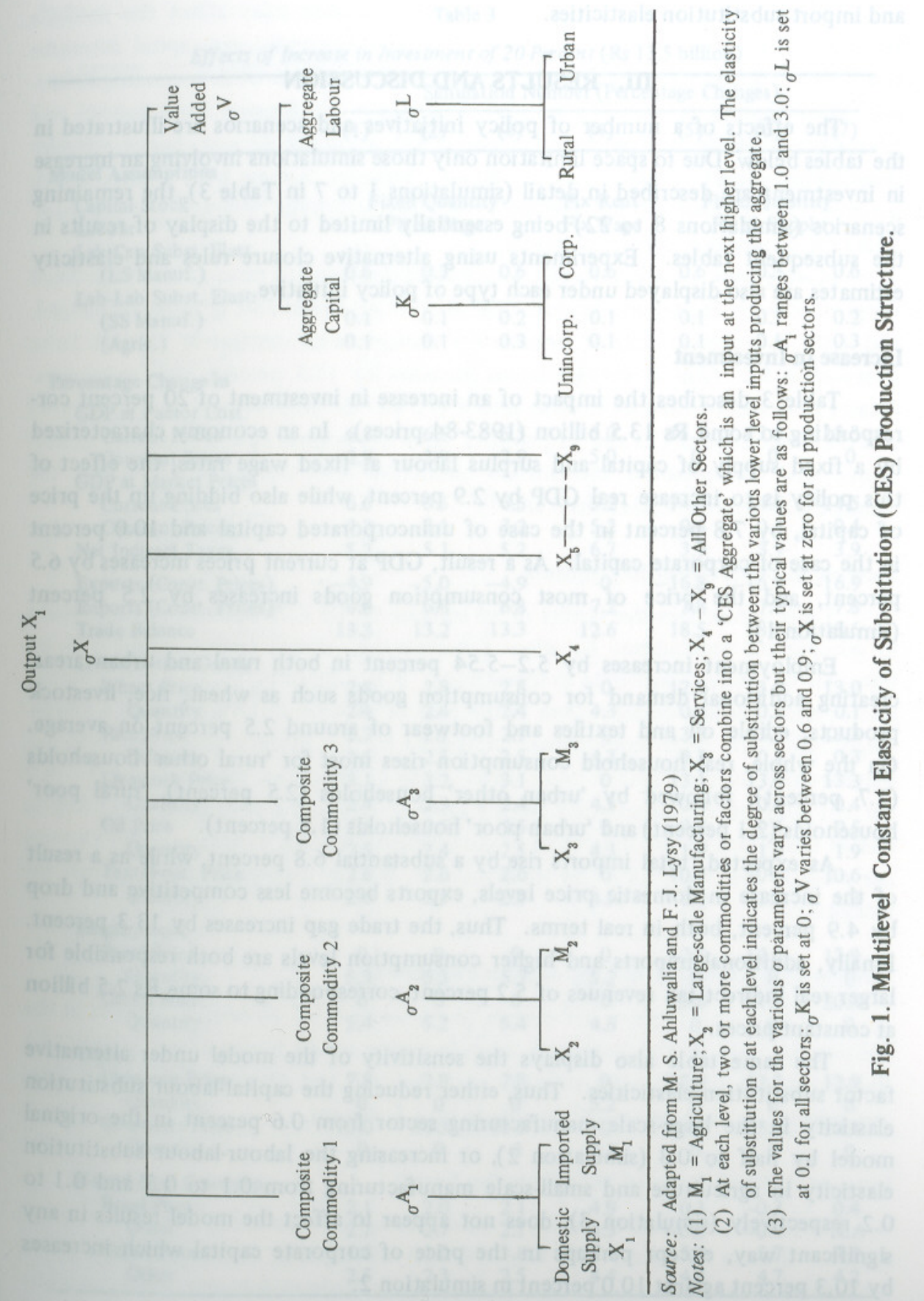


Table 3

\section{RESULTS AND DISCUSSION}

The effects of a number of policy initiatives and scenarios are illustrated in the tables below. Due to space limitation only those simulations involving an increase in investment are described in detail (simulations 1 to 7 in Table 3), the remaining scenarios (simulations 8 to 22 ) being essentially limited to the display of results in the subsequent tables. Experiments using alternative closure rules and elasticity estimates are also displayed under each type of policy initiative.

\section{Increase in Investment}

Table 3 describes the impact of an increase in investment of 20 percent corresponding to some Rs 13.5 billion (1983-84 prices). In an economy characterized by a fixed supply of capital and surplus labour at fixed wage rates, the effect of this policy is to increase real GDP by 2.9 percent, while also bidding up the price of capital, by 7.8 percent in the case of unincorporated capital and 10.0 percent in the case of corporate capital. As a result, GDP at current prices increases by 6.5 percent, and the price of most consumption goods increases by 2.5 percent (simulation 1).

Employment increases by $5.2-5.54$ percent in both rural and urban areas, creating additional demand for consumption goods such as wheat, rice, livestock products, edible oil and textiles and footwear of around 2.5 percent on average. On the whole, real household consumption rises most for 'rural other' households (2.7 percent), followed by 'urban other' households ( 2.5 percent), 'rural poor' households ( 2.1 percent) and 'urban poor' households ( 1.8 percent).

As expected, total imports rise by a substantial 6.8 percent, while as a result of the increase in domestic price levels, exports become less competitive and drop by 4.9 percent, both in real terms. Thus, the trade gap increases by 13.3 percent. Finally, additional imports and higher consumption levels are both responsible for larger real indirect tax revenues of 5.2 percent, corresponding to some Rs 2.5 billion at constant prices.

The same table also displays the sensitivity of the model under alternative factor substitution elasticities. Thus, either reducing the capital-labour substitution elasticity in the large-scale manufacturing sector from 0.6 percent in the original model by half to 0.3 (simulation 2), or increasing the labour-labour substitution elasticity in agriculture and small-scale manufacturing from 0.1 to 0.3 and 0.1 to 0.2 respectively (simulation 3 ), does not appear to affect the model results in any significant way, except perhaps in the price of corporate capital which increases by 10.3 percent against 10.0 percent in simulation 2 .
Effects of Increase in Investment of 20 Percent (Rs 13.5 billion) Simulation Number (Percentage Changes)

$\begin{array}{llllll}(1) \quad(2) \quad(3) \quad \text { (4) } & \text { (5) }\end{array}$

\begin{tabular}{|c|c|c|c|c|c|c|c|}
\hline \multicolumn{8}{|l|}{ Model Assumptions } \\
\hline $\begin{array}{l}\text { Capital Stock } \\
\text { Labour }\end{array}$ & \multicolumn{3}{|c|}{$\begin{array}{l}\text { Fixed Quantity } \\
\text { Fixed Wage }\end{array}$} & $\begin{array}{l}\text { Fix Rent } \\
\text { Fix Wage }\end{array}$ & \multicolumn{3}{|c|}{ Fixed Quantity } \\
\hline $\begin{array}{l}\text { Lab-Cap Subst. Elast. } \\
\text { (LS Manuf.) }\end{array}$ & 0.6 & 0.3 & 0.6 & 0.6 & 0.6 & 0.3 & 06 \\
\hline $\begin{array}{l}\text { Lab-Lab Subst. Elast. } \\
\text { (SS Manuf.) }\end{array}$ & & & & & & & \\
\hline $\begin{array}{l}\text { (SS Manur.) } \\
\text { (Agric.) }\end{array}$ & 0.1 & 0.1 & 0.2 & 0.1 & 0.1 & 0.1 & 0.2 \\
\hline \multirow{2}{*}{\multicolumn{8}{|c|}{ Percentage Change in }} \\
\hline & & & & & & & \\
\hline \multicolumn{8}{|l|}{ GDP at Factor Cost } \\
\hline Current Prices & 6.5 & 6.5 & 6.5 & 5.0 & 15.3 & 15.4 & 15.3 \\
\hline \multirow{2}{*}{\multicolumn{8}{|c|}{ GDP at Market Prices }} \\
\hline & & & & & & & \\
\hline Current Prices & 6.5 & 6.5 & 6.5 & 5.2 & 14.5 & 14.6 & 14.5 \\
\hline Constant Prices & 3.2 & 3.1 & 3.2 & 5.2 & 0.4 & 0.4 & 0.4 \\
\hline Net Indirect Taxes & 5.2 & 5.1 & 5.2 & 6.7 & 3.9 & 3.9 & 3.9 \\
\hline Exports (Const. Prices) & -4.9 & -5.0 & -4.9 & 0 & -16.8 & -16.9 & -16.9 \\
\hline Imports (Const. Prices) & 6.8 & 6.8 & 6.8 & 7.2 & 7.8 & 7.8 & 7.8 \\
\hline Trade Balance & 13.3 & 13.2 & 13.3 & 12.6 & 18.5 & 18.6 & 18.6 \\
\hline \multicolumn{8}{|l|}{ Consumption Goods } \\
\hline Wheat Price & 2.8 & 2.8 & 2.8 & 0 & 12.9 & 13.0 & 13.0 \\
\hline Quantity & 2.4 & 2.4 & 2.4 & 4.3 & 0.4 & 0.5 & 0.1 \\
\hline Rice Price & 2.7 & 2.7 & 2.7 & 0 & 13.3 & 13.3 & 13.3 \\
\hline Quantity & 2.5 & 2.5 & 2.5 & 4.3 & 0.3 & 0.3 & 0.3 \\
\hline Livestock Price & 3.1 & 3.2 & 3.1 & 0 & 13.1 & 13.0 & 13.3 \\
\hline Quantity & 2.4 & 2.3 & 2.4 & 4.3 & 0.4 & 0.4 & 0.4 \\
\hline Oil Price & 2.5 & 2.5 & 2.5 & 0 & 9.5 & 9.5 & 9.5 \\
\hline Quantity & 2.5 & 2.4 & 2.5 & 4.3 & 1.9 & 1.9 & 1.9 \\
\hline Text/Foot. Price & 2.6 & 2.6 & 2.6 & 0 & 10.5 & 10.6 & 10.6 \\
\hline Quantity & 2.6 & 2.5 & 2.6 & 4.5 & 1.2 & 1.2 & 1.3 \\
\hline \multicolumn{8}{|l|}{ Employment } \\
\hline Rural Price & 0 & 0 & 0 & 0 & 12.5 & 12.3 & 12.9 \\
\hline Quantity & 5.3 & 5.3 & 5.3 & 5.2 & 0 & 0 & 0 \\
\hline Urban Price & 0 & 0 & 0 & 0 & 20.8 & 21.4 & 20.3 \\
\hline Quantity & 5.4 & 5.2 & 5.4 & 4.8 & 0 & 0 & 0 \\
\hline \multicolumn{8}{|l|}{ Capital } \\
\hline Unincorp Price & 7.8 & 7.9 & 7.8 & 0 & 12.8 & 12.7 & 12.9 \\
\hline Quantity & 0 & 0 & 0 & 5.2 & 0 & 0 & 0 \\
\hline Corporate Price & 10.0 & 10.3 & 10.0 & 0 & 24.7 & 25.0 & 24.4 \\
\hline Quantity & 0 & 0 & 0 & 4.3 & 0 & 0 & 0 \\
\hline \multicolumn{8}{|l|}{ H-hold Real Consump. } \\
\hline Rural Poor & 2.1 & 2.0 & 2.1 & 4.9 & 0.1 & -0.3 & 0.4 \\
\hline Other & 2.7 & 2.7 & 2.7 & 4.3 & -0.8 & -0.9 & N.A \\
\hline Urban Poor & 1.8 & 1.0 & 1.8 & 4.1 & 5.3 & 5.7 & 4.9 \\
\hline Other & 2.5 & 2.3 & 2.5 & 4.4 & 4.4 & 4.7 & 4.2 \\
\hline
\end{tabular}


On the other hand, changing the model's closure rules affect the model's results dramatically. Thus, removing the supply constraint on capital increases real GDP by 5.0 percent instead of the previous 2.9 percent while increasing household consumption by $4.1-4.9$ percent (simulation 4 ). Because both capital and labour are available at fixed price, prices in the economy do not change, thereby maintaining export competitiveness. Imports however increase by a slightly higher amount (7.2 instead of 6.8 percent), creating additional indirect tax revenues. This type of model is a fix-price model.

Moving now to a completely constrained neoclassical formulation with fixed supplies of both capital and labour, GDP at constant factor cost remains unchanged, and GDP at constant market prices only changes with changes in indirect taxes (simulation 5). GDP at current prices increases by 15.3 percent, due to large increases of prices of rural and urban labour (12 and 21 percent) and unincorporated and corporate capital (13 and 25 percent). As in the original model, changing labourcapital and labour-labour substitution elasticities does not appear to affect the results significantly (simulations 6 and 7).

\section{Increase in Government Expenditure}

Table 4 describes the results of an increase of Rs 13.5 billion or 26.8 percent in government expenditure to allow a comparison of this policy option with an injection of similar magnitude in investment. It is interesting to note that employment effects are less uniform than in the case of increase of investment of a similar magnitude, with urban employment increasing by 8.7 percent compared with 3.3 percent only for rural labour. As a result, urban consumption increases by $3.5-4.9$ percent while rural consumption levels stagnate ( -1.0 to 1.0 percent change). This is a clear indication of the urban bias of government spending in general. Also imports rise more in the case of increase in investment, thereby producing larger indirect tax receipts.

\section{Increase in Indirect Tax in Large-scale Manufacturing}

Table 4 also displays the effects of an increase of 10 and 20 percent in the indirect tax rate of the large-scale manufacturing sector (simulations 11 and 12). Because of the overall contraction in the economy and decrease in imports, total real indirect tax revenues in fact also drop by 1.5 percent.

\section{Increase in World Prices of Manufacturing Goods}

In this experiment, the price of manufacturing goods is allowed to rise by 20 percent, thereby not only affecting the cost of imports, but also increasing the price offered to exporters of manufactured goods made in Pakistan. Because of the
Table 4

Effects of Increase in Government Expenditure and Indirect Taxes

Simulation Number (Percentage Changes)

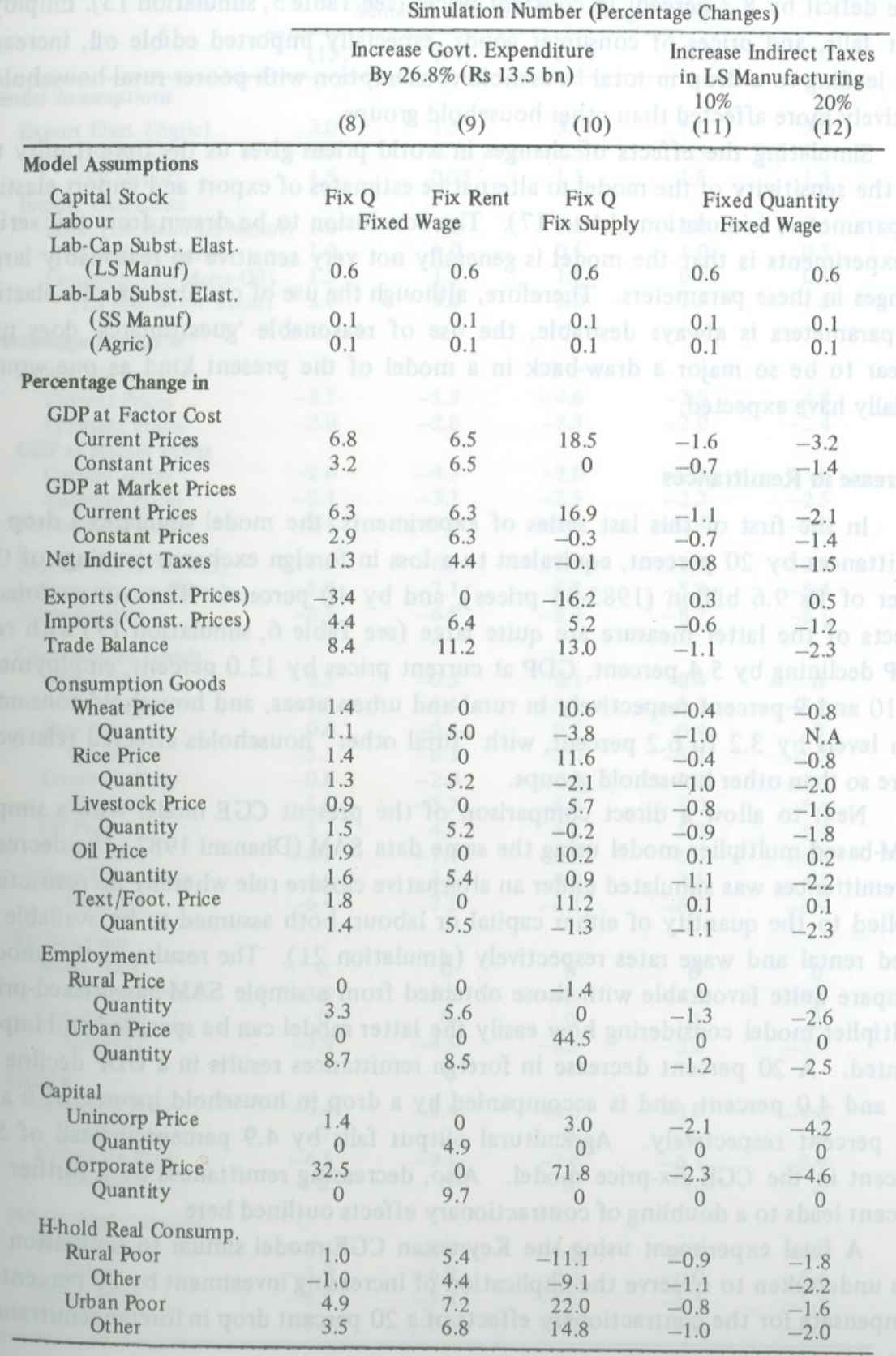


much larger value of imports relative to that of exports, this results in a contraction of real GDP, exports rising substantially relative to imports, thus decreasing the trade deficit by 8.7 percent in constant prices (see Table 5, simulation 13). Employment falls, and prices of consumer goods, especially imported edible oil, increase thus leading to a drop in total household consumption with poorer rural households relatively more affected than other household groups.

Simulating the effects of changes in world prices gives us the opportunity to test the sensitivity of the model to alternative estimates of export and import elasticity parameters (simulations 14 to 17). The conclusion to be drawn from this series of experiments is that the model is generally not very sensitive to reasonably large changes in these parameters. Therefore, although the use of country-specific elasticity parameters is always desirable, the use of reasonable 'guesstimates' does not appear to be so major a draw-back in a model of the present kind as one would initially have expected.

\section{Decrease in Remittances}

In the first of this last series of experiments, the model simulates a drop in emittances by 20 percent, equivalent to a loss in foreign exchange earnings of the order of Rs 9.6 billion (1983-84 prices), and by 40 percent. The contractionary effects of the latter measure are quite large (see Table 6, simulation 19) with real GDP declining by 5.4 percent, GDP at current prices by 12.0 percent, employment by 10 and 9 percent respectively in rural and urban areas, and household consumption levels by 3.2 to 6.2 percent, with "rural other" households affected relatively more so than other household groups.

Next to allow a direct comparison of the present CGE model with a simple SAM-based multiplier model using the same data SAM (Dhanani 1987), the decrease in remittances was simulated under an alternative closure rule whereby no restriction applied to the quantity of either capital or labour, both assumed to be available at fixed rental and wage rates respectively (simulation 21 ). The results of this model compare quite favourable with those obtained from a simple SAM-based fixed-price multiplier model considering how easily the latter model can be specified and implemented. A 20 percent decrease in foreign remittances results in a GDP decline of 4.7 and 4.0 percent, and is accompanied by a drop in household income of 6 and 6.7 percent respectively. Agricultural output falls by 4.9 percent instead of 5.7 percent in the CGE fix-price model. Also, decreasing remittances by a further 20 percent leads to a doubling of contractionary effects outlined here

A final experiment using the Keynesian CGE model similar to simulation 18 was undertaken to observe the implication of increasing investment by 20 percent to compensate for the contractionary effects of a 20 percent drop in foreign remittances
Table 5

Increase in World Prices of Manufacturing Goods by 20 Percent

\begin{tabular}{|c|c|c|c|c|c|}
\hline & \multicolumn{5}{|c|}{ Simulation Number (Percentage Changes) } \\
\hline & (13) & (14) & (15) & $(16)$ & (17) \\
\hline \multicolumn{6}{|l|}{ Model Assumptions } \\
\hline $\begin{array}{c}\text { Export Elast. (Agric) } \\
\text { (LS Manuf) }\end{array}$ & $\begin{array}{l}3.0 \\
1.5\end{array}$ & $\begin{array}{l}1.5 \\
0.75\end{array}$ & $\begin{array}{l}3.0 \\
1.5\end{array}$ & $\begin{array}{l}3.0 \\
1.5\end{array}$ & $\begin{array}{l}3.0 \\
1.5\end{array}$ \\
\hline (SS Manuf) & 1.5 & 0.75 & 1.5 & 1.5 & 1.5 \\
\hline \multicolumn{6}{|c|}{ Import Elasticities } \\
\hline Prod. (LS Manu-LS Manuf) & f) 1.0 & 1.0 & 0.5 & 1.0 & 0.5 \\
\hline (LS Manu-Agric) & 1.0 & 1.0 & 0.5 & 1.0 & 0.5 \\
\hline Consump. (LS Manu-Oil) & 1.5 & 1.5 & 1.5 & 0.75 & 0.75 \\
\hline (LS Manu-Oth. Food) & 3.0 & 3.0 & 3.0 & 1.5 & 1.5 \\
\hline \multicolumn{6}{|l|}{ Percentage Change in } \\
\hline $\begin{array}{l}\text { GDP at Factor Cost } \\
\text { Current Prices }\end{array}$ & & & & & \\
\hline Current Prices & -3.7 & $\begin{array}{r}-5.9 \\
-28\end{array}$ & -4.6 & -3.9 & -4.8 \\
\hline Constant Prices & -2.0 & -2.8 & -2.3 & -2.0 & \\
\hline \multicolumn{6}{|l|}{ GDP at Market Prices } \\
\hline Current Prices & -2.6 & $\begin{array}{l}-4.3 \\
-3.1\end{array}$ & $\begin{array}{l}-3.0 \\
-2.5\end{array}$ & $\begin{array}{l}-2.3 \\
-2.2\end{array}$ & $\begin{array}{l}-3.2 \\
-2.5\end{array}$ \\
\hline $\begin{array}{l}\text { Constant Prices } \\
\text { Net Indirect. Taxes }\end{array}$ & $\begin{array}{l}-2.1 \\
-2.4\end{array}$ & $\begin{array}{l}-3.1 \\
-3.9\end{array}$ & $\begin{array}{l}-2.5 \\
-2.5\end{array}$ & $\begin{array}{l}-2.2 \\
-2.4\end{array}$ & $\begin{array}{l}-2.5 \\
-2.5\end{array}$ \\
\hline Exports (Const. Prices) & 11.8 & 6.5 & 12.6 & 12.0 & 12.9 \\
\hline Imports (Const. Prices) & -5.9 & -7.1 & -5.5 & -5.8 & -5.4 \\
\hline Trade Balance & -8.7 & -6.5 & -8.3 & -8.7 & -8.1 \\
\hline \multicolumn{6}{|l|}{ Consumption Goods } \\
\hline Wheat Price & 0.5 & -0.5 & 0.1 & 0.4 & 0 \\
\hline Quantity & -5.3 & -6.1 & -5.6 & -5.3 & -5.7 \\
\hline Rice Price & 0.5 & -0.5 & 0.1 & 0.4 & 0 \\
\hline Quantity & -5.3 & -6.1 & -5.6 & -5.3 & -5.7 \\
\hline Livestock Price & -0.8 & -2.0 & -1.3 & -0.9 & -1.4 \\
\hline Quantity & -5.0 & -5.7 & -5.3 & -5.0 & -5.4 \\
\hline Oil Price & 5.7 & 4.7 & 5.4 & 5.8 & 5.4 \\
\hline Quantity & -6.3 & -7.1 & -6.7 & -6.4 & -6.8 \\
\hline Text/Foot. Price & 4.6 & 3.6 & 4.2 & 4.5 & 4.1 \\
\hline Quantity & -6.4 & -7.2 & -6.1 & -6.5 & -6.9 \\
\hline \multicolumn{6}{|l|}{ Employment } \\
\hline Rural Price & 0 & 0 & 0 & 0 & 0 \\
\hline Quantity & -3.9 & -5.5 & -4.6 & -4.1 & -4.7 \\
\hline Urban Price & 0 & 0 & 0 & 0 & 0 \\
\hline Quantity & -2.9 & -4.5 & -3.5 & -3.0 & -3.7 \\
\hline \multicolumn{6}{|l|}{ Capital } \\
\hline Unincorp Price & -3.4 & -6.4 & -4.6 & -3.7 & -5.0 \\
\hline Quantity & 0 & 0 & 0 & 0 & 0 \\
\hline Corporate Price & -6.5 & -9.1 & -7.6 & -6.7 & -7.9 \\
\hline Quantity & 0 & 0 & 0 & 0 & 0 \\
\hline \multicolumn{6}{|l|}{ H-hold Real Consump. } \\
\hline Rural Poor & -6.4 & -6.9 & -6.6 & -6.4 & -6.6 \\
\hline Other & -5.9 & -6.9 & -6.3 & -6.0 & -6.4 \\
\hline Urban Poor & -5.5 & -5.8 & -5.6 & -5.5 & -5.7 \\
\hline Other & -5.9 & -6.6 & -6.2 & -6.0 & -6.3 \\
\hline
\end{tabular}


Table 6

Effects of Decrease in Remittances

by 20 Percent (Rs 9.6 Billion) and 40 Percent (Rs 19.2 Billion)

\begin{tabular}{|c|c|c|c|c|c|}
\hline \multirow{3}{*}{ Decrease by } & \multicolumn{5}{|c|}{ Simulation Number (Percentage Changes) } \\
\hline & $20 \%$ & $40 \%$ & $20 \%$ & $20 \%$ & $40 \%$ \\
\hline & (18) & (19) & (20) & (21) & (22) \\
\hline \multicolumn{6}{|l|}{ Model Assumptions } \\
\hline Capital Stock & \multirow{2}{*}{\multicolumn{2}{|c|}{$\begin{array}{c}\text { Fixed Quantity } \\
\text { Fixed Wage }\end{array}$}} & \multirow{2}{*}{\multicolumn{2}{|c|}{$\begin{array}{l}\text { Fixed Rent } \\
\text { Fixed Wage }\end{array}$}} & Fixed Quantity \\
\hline Wages & & & & & Fixed Wage \\
\hline Increase Investment by & - & - & - & - & $20 \%$ \\
\hline \multicolumn{6}{|l|}{ Percentage Change in } \\
\hline \multicolumn{6}{|l|}{ GDP at Factor Cost } \\
\hline Current Prices & -6.0 & -12.0 & -4.7 & -9.5 & 0.2 \\
\hline Constant Prices & -2.7 & -5.4 & -4.7 & -9.5 & 0.2 \\
\hline \multicolumn{6}{|l|}{ GDP at Market Prices } \\
\hline Current Prices & -5.9 & -15.3 & & & 0.5 \\
\hline Constant Prices & -2.8 & -7.7 & & & 0.4 \\
\hline Net Indirect Taxes & -4.5 & -8.2 & -4.6 & -9.1 & 2.1 \\
\hline Exports (Const. Prices) & 5.2 & 10.9 & 0 & 0 & 0 \\
\hline Imports (Const. Prices) & -3.6 & -7.3 & -4.0 & -8.1 & 3.2 \\
\hline Trade Balance & -7.8 & -15.8 & -7.0 & -14.0 & 5.5 \\
\hline \multicolumn{6}{|l|}{ Consumption Goods } \\
\hline Wheat Price & -2.7 & -5.5 & 0 & 0 & 0 \\
\hline Quantity & -5.1 & -10.4 & -6.7 & -13.4 & -2.4 \\
\hline Rice Price & -2.6 & -5.3 & 0 & 0 & 0 \\
\hline Quantity & -5.1 & -10.4 & -6.7 & -13.4 & -2.5 \\
\hline Livestock Price & -3.1 & -6.3 & 0 & 0 & 0 \\
\hline Quantity & -5.0 & -10.4 & -6.7 & -13.5 & -2.5 \\
\hline Oil Price & -2.4 & -4.9 & 0 & 0 & 0 \\
\hline Quantity & -4.8 & -9.9 & -6.5 & -13.0 & -2.3 \\
\hline Text/Foot. Price & -2.5 & -5.1 & 0 & 0 & 0 \\
\hline Quantity & -5.2 & -10.7 & -6.9 & -13.8 & -2.5 \\
\hline \multicolumn{6}{|l|}{ Employment } \\
\hline Rural Price & 0 & 0 & 0 & 0 & 0 \\
\hline Quantity & -5.1 & -10.3 & -5.0 & -10.0 & 0.1 \\
\hline Urban Price & 0 & 0 & 0 & $\theta$ & 0 \\
\hline Quantity & -4.6 & -9.3 & -4.1 & -8.1 & 0.1 \\
\hline \multicolumn{6}{|l|}{ Capital } \\
\hline Unincorp Price & -7.5 & -14.8 & 0 & 0 & 0 \\
\hline Quantity & 0 & 0 & -5.1 & -10.2 & 0 \\
\hline Corporate Price & -8.6 & -16.8 & 0 & 0 & 0.6 \\
\hline Quantity & 0 & 0 & -4.1 & -8.2 & 0 \\
\hline \multicolumn{6}{|l|}{ H-hold Real Consump. } \\
\hline Rural Poor & -3.2 & -6.7 & -5.8 & -11.5 & -1.0 \\
\hline Other & -6.2 & -12.8 & -7.6 & -15.2 & -3.4 \\
\hline Urban Poor & -4.1 & -8.4 & -6.3 & -12.5 & -2.2 \\
\hline Other & -4.3 & -8.6 & -5.9 & -11.9 & -1.6 \\
\hline
\end{tabular}

on the economy. Simulation 22 shows that GDP remains at its original level, and on the whole an increase in investment of 20 percent can avert the most serious of the contractionary effects on the economy imposed by a 20 percent decrease in remittances.

\section{CONCLUDING REMARKS}

The previous section attempted to quantify the economic effects on overall GDP, imports, exports, trade deficit, employment levels, prices of food and other essential consumer items, wages and rental rates and consumption levels of various household groups of a number of policy options such as increase in investment, government expenditures and indirect taxes; and external shocks such as increases in world prices of manufacturing goods and changes in foreign remittances. The list of experiments undertaken in this paper is by no means exhaustive, and many other types of policy interventions can be simulated with relatively little difficulty.

Sensitivity analysis carried out on a number of elasticity parameters for which country-specific estimates were not available suggested that the absence of such data was not as significant a draw-back as initially expected. This has two implications: either their exact magnitudes do not matter so much, in which case this type of model can be set up with borrowed or estimated elasticities; or they do matter, and the particular type of model implemented here is not very sensitive to, at times, quite large variations in these parameters. The present paper cannot answer this very important question, but can only raise the issue of the appropriateness or otherwise of relying so much on the concept of elasticity in general equilibrium model building.

The effects on income distribution are relatively small between household groups, except in the case of government expenditure. The main reason for this is that the model takes the distribution of ownership of factors of production as given, and as quantified in the data SAM. For a better analysis of the possibilities of changing this income distribution, policy intervention in the areas of asset redistribution, as in the case of land-ownership, may need to be considered in order to alter significantly the present pattern of income distribution.

Some of the policy options and external shocks above were tested under two sets of alternative closure rules; the first one assuming a completely constrained economy where both capital and labour were fully employed and where real GDP could not therefore increase (neoclassical specification), and the second one assuming the exact opposite, i.e. excess capacity and unemployment, leading to a fix-price CGE model. The results of the latter confirmed that a simple SAM-based fix-price multiplier model provided quite a good guide to the testing of policy alternatives compared with the much more sophisticated fix-price CGE model in circumstances and at a point in time where excess capacity in various production sectors as well a 


\section{REFERENCES}

Ahluwalia M. S., and F. J. Lysy (1979). "Welfare Effects of Demand Management policies: Impact Multipliers Under Alternative Model Structures". Journal of Policy Modelling. Vol. 1; No. 3.

Dhanani, S. (1987). "Application of a Social Accounting Matrix (SAM) Fixed-Price Multiplier Model to Agricultural Sector Analysis in Pakistan". Unpublished D.Phil Thesis, Institute of Agricultural Economics, Oxford University. Oxford.

\section{Comments on \\ "A SAM-based General Equilibrium Model of the Pakistan Economy 1983-84"}

CGE models, which constitute a particular class within a broad range of alternative policy analysis models provided by economic theory, can contribute significantly to the formulation of consistent policies by showing the essential relationships between economic variables.

Macroeconomic models, which are set in a SAM framework, have been distinguished into two types (by Thorbecke). The so-called first-generation models have an essentially linear relationship to the SAM accounting structure. The secondgeneration models, also known as CGE models, are non-linearly related to the SAM, in which prices are endogenous and adjust so that markets are cleared and, in which, production relations are characterized by constant elasticities of substitution. As the title of the paper makes it obvious Dhanani's model belongs to the latter class of models.

The first generation class of models, or the simple SAM multiplier models enable to explore important features of the economy and also provide estimations of the impact of various types of policies on the economy. The SAM multiplier models are, however, subject to the same criticism as input-output multiplier models e.g. that price effects are ignored and that production activities have excess capacity, implying a Keynesian underlying structure. But they do provide useful estimates, though on the basis of strong assumptions, and can be the starting point for policy debate.

It is interesting that Dhanani's comparison of the results of the SAM Multiplier Model with those of a Fix-price CGE Model do not show much difference. The reason given is excess capacity in production activities and labour unemployment, which, as explained earlier, are the underlying assumptions for the SAM Multiplier Model. It can also be expected that general equilibrium feed back effects are small in a developing economy. In such a situation, CGE models may also behave in a way similar to the SAM Multiplier models even when exogenous shocks are economy wide.

One of the most important obstacles to the use of CGE models is the necessity for a complete set of base period accounts for the economy. Dhanani uses an explicit SAM framework for his model. It is obvious that the collection of the initial data set and the compilation of the SAM (an enormous exercise in itself, which must have 
taken the author much longer time than the estimation of the model) has contributed to better calibration of initial conditions and formulation of the conceptual model. However, as the data base is critical to the entire exercise of using CGE models for policy analysis, because of its importance in determining simulated price, output and income effects, I must mention that the quality of some of the data leaves much to be desired. For example, the Input Output Table for 1975-76, which has been updated to the year 1983-84, (with the updating exercise itself debatable, not simply because of the inevitable use of the RAS method) is based on the doubtful Census of Manufacturing Industries for that year. The results of the various exercises done in the paper are, therefore, limited by these factors.

The assumptions required to limit parameters and obtain solutions also suggests that there are important restrictions on the application of CGE models for policy analysis e.g. the choice of closure rules determines, in an important way, the structure and behaviour of the model and, consequently, the analysis of alternative measures. The comparison of the results of exercises under two different sets of closure rules, as Dhanani has done, does not resolve the issue about which closure rule is best. But it does yield a range of results corresponding to different alternatives. Dhanani has done a number of policy experiments, using different sets of closure rules, alternative estimates of elasticity parameters etc., to evaluate the impact on employment, prices, trade balance and income and consumption patterns of increases in investment, government expenditure, indirect taxes, world prices of traded goods and decreases in foreign remittances, which can be successfully addressed within the SAM and CGE modelling frameworks.

Despite the many limitations to the application of CGE models in policy analysis, such a framework plays an important role in bringing together a large amount of information in a consistent framework and by identifying the essential relationships, which are relevant to the particular policies being examined. Dhanani has done extremely useful and commendable work in compiling a disaggregated SAM for Pakistan and then using it for policy analysis within a general equilibrium framework.

Khwaja Sarmad

Pakistan Institute of

\section{Development Economics,}

